\title{
Energy Usage During Drying Systems
}

ISSN: 2637-8035

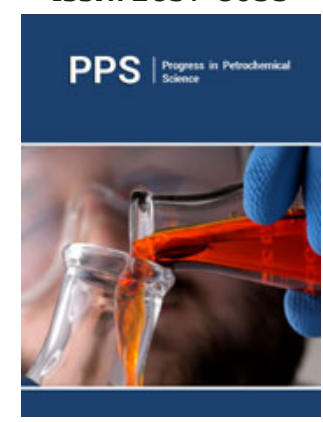

*Corresponding author: Anita Kovac Kralj, Faculty of Chemistry and Chemical Engineering, Slovenia

Submission: March 10, 2020

Published: 眥 March 16, 2020

Volume 3 - Issue 2

How to cite this article: Anita Kovac Kralj. Energy Usage During Drying Systems. Progress Petrochem Sci .3(2). PPS.000559.2020.

DOI: $10.31031 /$ PPS.2020.03.000559

Copyright@ Anita Kovac Kralj, This article is distributed under the terms of the Creative Commons Attribution 4.0 International License, which permits unrestricted use and redistribution provided that the original author and source are credited.

\author{
Anita Kovac Kralj* \\ Faculty of Chemistry and Chemical Engineering, Slovenia
}

\section{Introduction}

Over recent years, engineers and scientists have directed their attentions to the waste heat flow rate and mass recoveries for cheaper energy and mass generation. Mass and energy reusage techniques can be useful for increasing the efficiencies of conventional energy and mass systems. The re-usage of waste heat would have positive effects on the amount of resources and waste and pollutants generated within industries. Waste-heat recovery techniques that are environmentally friendly and have technical and economic advantages should be assessed for possible contributions to the energy economy and the national economy. The mass and energy re-usage technique, as a simple method by using air heat flow rate from the dryer, is based on more efficient steam generation targets, using pinch analysis and/or MINLP. The benefit of this technique allows the maximal recovery of heat and mass. This technique is a simple method for estimating of the maximal the maximal recovery of heat and mass.

The aim of the presented research is an investigation of heat flow rate and condensate recovery improvement opportunities within food plants. The mass and energy re-usage of air outlet after drying indicates major potential for improvement within the following drying systems:

A. Air outlet heat flow rate recovery.

B. Condensate recovery.

Modified existing sugar process allows additional profit of 756,000EUR/a by using the replacing of low-pressure steam with air heat flow rate from dryer.

\section{Energy Usage During Drying Systems for Existing Problems}

The mass and energy re-usage technique is a very simple method that was tested during existing sugar production. The existing evaporators used low-pressure steam for heating, which could be replaced by heat flow rate from the dryer.

A. The first step of this technique is represented the existing heat flow rates, and the inlet/outlet temperatures of all the cold streams through the evaporators, which can be heated by using the air outlet from the dryer. The process cold streams of the evaporators are introduced by using the grand composite curve (GCC) with $\Delta_{\min } \mathrm{T}=7^{\circ} \mathrm{C}$.

B. The second step is to analyse the air outlet stream from the dryer. The air outlet temperature was $125{ }^{\circ} \mathrm{C}$. The air stream included the $36,300 \mathrm{~kg} / \mathrm{h}$ of water steam and $41,350 \mathrm{~kg} / \mathrm{h}$ of gases $\left(\mathrm{O}_{2}, \mathrm{~N}_{2}, \mathrm{CO}_{2}\right)$. The total air heat flow rate from the dryer was $20,400 \mathrm{~kW}$ (if the air stream was cooled to $67^{\circ} \mathrm{C}$ ).

The usable air heat flow rate $\left(Q_{\text {air }}\right)$ was $14.100 \mathrm{~kW}$, which shared with the vapour $\left(Q_{\text {vap }}=1,100 \mathrm{~kW}\right)$ and condensing $\left(Q_{\text {cond }}=13,000 \mathrm{~kW}\right)$ parts and located above the GCC of cold streams of evaporators (Figure 1$)$. The condensing heat flow rate $\left(Q_{\text {cond,i) }}\right.$ is split into smaller parts regarding the number of individual evaporators $\left.{ }_{(} \mathrm{N}_{\mathrm{ev}}\right)$. The vapour heat flow rate was too small for splitting. The inlet and outlet temperatures of the vapour air streams $\left(T_{\text {vap,in, }}\right.$ $T_{\text {vapout })}$ were $125^{\circ} \mathrm{C}$ and $90^{\circ} \mathrm{C}$. The started condensing temperature $\left(T_{\text {cond) }}\right.$ was $90^{\circ} \mathrm{C}$. The output temperature ( $T_{\text {cond,out), }}$ fraction of condensing $f_{\text {cond) }}$ and condensing heat flow rate (in $\mathrm{kW}$ ) would be calculated by using a linear function. 


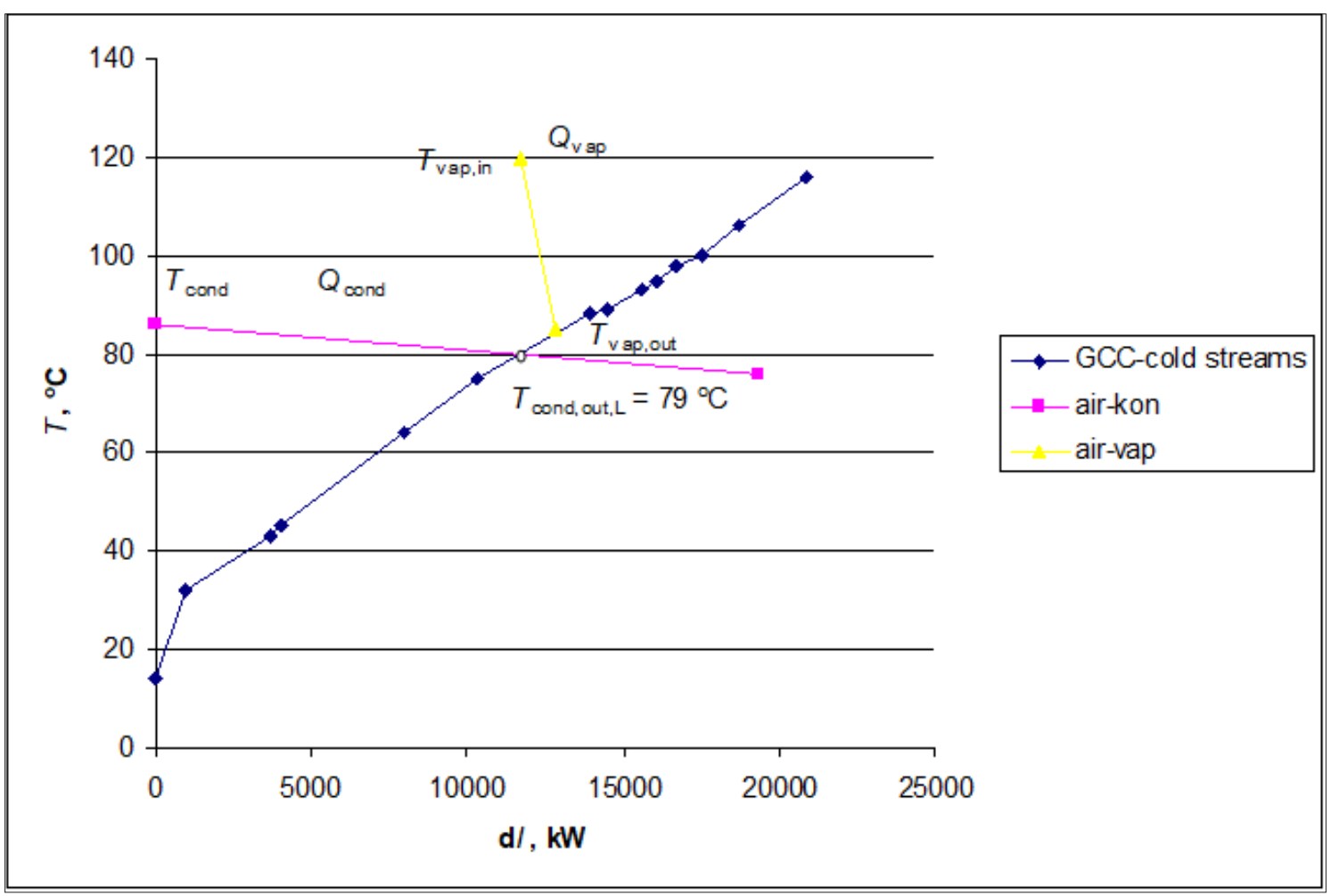

Figure 1: The diagram of energy re-usage techniques for the existing evaporators. 